\title{
Sixteenth- and Seventeenth-Century Russian Lexicons: Peculiarities of the First Representatives*
}

\author{
KIRA KOVALENKO \\ Институт лингвистических исследований Российской академии наук, \\ Тучков пер., д. 9, RU-199053 Санкт-Петербург \\ E-mail: kira.kovalenko@gmail.com
}

(Received: 3 July 2016; accepted: 27 September 2016)

\begin{abstract}
The present paper is devoted to the first Russian manuscript lexicons, which were commonly used in Moscovy during the 16th and 17th centuries. The author discusses the origin of foreign words, literary sources, and principles of the organization of dictionary entries in synchrony and diachrony.
\end{abstract}

Keywords: lexicography, dictionaries, lexicons, manuscripts, Old Russian literature

The beginnings of Russian lexicography go far back into the past. The first lexicographical compilations which have come down safely to our time were made in the 13th century. It was a list of symbols from the Psalms, a list of obscure words from John Climacus's The Ladder of Divine Ascent, and some glossaries to other translated texts. Starting in the middle of the 16th century, they formed the basis of a new lexicographical genre, the Russian manuscript dictionary, which is known as Lexicon or Azbukovnik.

According to the commonly accepted classification, there are 9 types of such lexicons: the lexicons of the preliminary stage, lexicons of types 1 to 7 , and the lexicons of the selective type (Kovtun 1989: 9-18). Lexicons of the preliminary stage are compilations of glossaries taken one after another, where the entries often have no particular order. Later, compilers began to order words alphabetically (according to the first letter). Furthermore, they started to use more sources; for example, glosses of obscure words and explanations of unknown concepts from Old Russian literature. Due to the numerous entries, such lexicons became independent books: while small glossaries had normally been attached to the more voluminous manuscripts initially, the lexicons began to form the main part of the manuscripts, to which other small articles (prefaces, grammars, and so on) were added. This point was the beginning of the lexicons in the full sense of the word. In my paper, I will concentrate on these first representatives - the lexicons of the first type.

* The research was financially supported by RGNF (Russian Humanitarian Scientific Fund), project № 13-34-01214 "Russian manuscript dictionaries as a lexicographical genre of Muscovy: traditions and innovations". 
In Russian libraries, 18 manuscripts of the first-type lexicons are stored. They are the Russian State Library (Moscow), Tikhonravov's collection: 445, Undolsky's collection: 975, 978, and 979; the State Historical Museum (Moscow), Uvarov's collection: 25, 311 (later - Uvar. 311), and 503, Synodalnoye collection: 835; the Russian National Library (St. Petersburg), Pogodin's collection: 1143, 1340, 1643, 1644, 1648, and 1655, Solovetskoe collection: 16/16 and 21/21, the Main collection: O.XVI.1 (later - O.XVI.1); the Library of the Russian Academy of Sciences (St. Petersburg), Arkhangelskoe collection: C107b. The first representative of the type is thought to have been compiled at the end of the 16th century but most copies came to us from the 17th century. In spite of their overall similarity, the copies are slightly different. I would like to describe two of them, which are very close to each other: O.XVI.1 and Uvar. 311.

The manuscript O.XVI. 1 is a paper codex $(14.7 \times 9.5 \mathrm{~cm})$ on 224 folios. It was created in the twenties of the 17 th century. The manuscript starts with a Preface, in which the reasons for compiling the lexicon and the abbreviations used are explained. The word entries go from f.7r up to f.118v, comprising 2283 entries with explained words and collocations of foreign origin. There are also some additional articles about grammar rules and works of the Holy Fathers.

The second manuscript (Uvar. 311) has 198 folios and was created at the same time as O.XVI.1, that is, in the twenties of the 17th century. The lexicon starts with a Preface, after which comes the lexicon containing 2274 entries.

In 1989, both manuscripts were printed (KovTUN 1989: 126-294).

The citations will be taken from the O.XVI.1 (we used the lower pagination in the manuscript). Examples from the second manuscript Uvar. 311 are quoted only where there are seriously different interpretations.

The name of the compilation varies: "The book called Alphavit containing unintelligible foreign words one can find in sacred Slavonic books" (O.XVI.1) or "The explanation of foreign words found in sacred books presented in alphabetical order for ease of reference" (Uvar. 311). So, here we find the foreign words (or collocations) and their explanations - these are the most important and obligatory parts of any entry. Above the foreign words, we can sometimes see small red letters which point to the source language. Most of them are from Greek. Of course, the Russian language was greatly influenced by Greek after the Christianization of Russia, that was the main reason for borrowing. Therefore, most Greek words are closely connected to the Christian church hierarchy, worship, and theological notions. For example:

\begin{tabular}{|c|c|c|}
\hline $\operatorname{An}^{c} л ъ$, посла́/нни ${ }^{k}$ (f.7r) & Apostle, messenger & cf. $\alpha \dot{\pi} \delta \sigma \tau \mathrm{o} \lambda \mathrm{o}$ \\
\hline Ди/лако, слуга (f.35r) & Diyakon, servant & 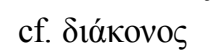 \\
\hline $\begin{array}{l}\text { Евангелие }\{2\}\}^{1}, \text { блгововьстие } \\
\text { (f.41r) }\end{array}$ & $\begin{array}{l}\text { Evangelie }\{\text { Greek }\}, \text { good } \\
\text { message }\end{array}$ & cf. $\varepsilon \dot{\alpha} \alpha \gamma \varepsilon \dot{\lambda} \lambda$ iov \\
\hline
\end{tabular}

\footnotetext{
${ }^{1}$ In curly braces, you can see references to the original language and literary source, placed in the manuscript over the words or in the margins.
} 


\begin{tabular}{|c|c|c|}
\hline Логосъ $\{2\}$, слово $(\mathrm{f} .73 \mathrm{v})$ & $\operatorname{Logos}\{$ Greek $\}$, word & cf. $\lambda$ ó $\gamma$ \\
\hline 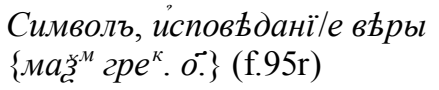 & $\begin{array}{l}\text { Simvol, faith confession } \\
\{\text { Maximus the Greek } 70\}\end{array}$ & cf. $\sigma u ́ \mu \beta \mathrm{o} \lambda \mathrm{ov}$ \\
\hline $\begin{array}{l}\text { Oýnocmacb }\{2\}, \text { составъ } \\
\text { (f.108r) }\end{array}$ & Upostas, content & cf. vं \\
\hline
\end{tabular}

Along with Greek words, there are also interpretations of Hebrew and Aramaic words. They came from books translated from Hebrew into Russian or from Greek books where Hebrew words were only transliterated:

\begin{tabular}{|c|c|c|}
\hline Адана́и $\{е в\} . m^{\pi} .2^{c} \partial b$ (f.7r) & Adanai $\{$ Jewish $\}$, God & cf. Hebrew אדני \\
\hline 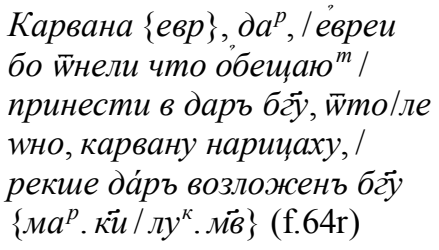 & $\begin{array}{l}\text { Karvana }\{\text { Jewish }\}, \text { gift } \\
\text { because Hebrew once have } \\
\text { promised to give a gift to God, } \\
\text { since then they named it } \\
\text { karvana, that is gift assigned } \\
\text { to God }\{\text { Mark } 28, \text { Luke } 42\}\end{array}$ & קָרברן cf. Hebrew \\
\hline 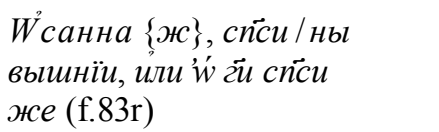 & $\begin{array}{l}\text { Osanna }\{\text { Jewish }\}, \text { save us } \\
\text { the Highest or God, save us } \\
\text { (f.83r) }\end{array}$ & $\begin{array}{l}\text { הושע נא נא } \\
\text { cf. Hebrew }\end{array}$ \\
\hline $\begin{array}{l}\text { Саваw }^{\theta}\{ж\}, \text { си́ла }\{\text { ïсаїа } \vec{a}\} \\
\text { (f.95r) }\end{array}$ & $\begin{array}{l}\text { Savaof }\{\text { Jewish }\}, \text { strength } \\
\{\text { Isaiah } 1\}\end{array}$ & צבאות cf. Hebrew \\
\hline$B a p z\{e в\}, / c \overrightarrow{H b}(\mathrm{f} .28 \mathrm{r})$ & $\operatorname{Var}\{$ Jewish $\}$, son & בר cf. Aramaic \\
\hline
\end{tabular}

Latin words reflect Russian relations with Western Catholic countries. Presumably, they represent words concerning religious lifestyle:

\begin{tabular}{|c|c|c|}
\hline Анима $\left\{p^{\prime \prime}\right\}, /$ диа (f.12r) & Anima $\{$ Roman $\}$, soul & cf. anima \\
\hline $\begin{array}{l}\text { Инъ у/рбибу, по поса́до } \\
\text { (f.56v) }\end{array}$ & In urbibu, in towns & cf. in urbibus \\
\hline $\begin{array}{l}\text { Ка/рдиналь }\left\{p^{\prime \prime}\right\}, \\
\text { мu }^{m} \text { рополи } \\
\text { (f.61r) }\end{array}$ & Kardinal $\{$ Roman $\}$, bishop & cf. cardinalis \\
\hline $\begin{array}{l}\text { Папа }\{p u\}, \text { nре/вь́шинїи } \\
\text { чнь (f.87r) }\end{array}$ & $\begin{array}{l}\text { Papa }\{\text { Roman }\} \text {, the highest } \\
\text { rank }\end{array}$ & cf. papa \\
\hline Силва $\{p u\}, л ь с ь(\mathrm{f} .99 \mathrm{v})$ & Silva $\{$ Roman $\}$, forest & cf. silva \\
\hline
\end{tabular}

Tatar and Turkish words occur much more rarely.

\begin{tabular}{|c|c|}
\hline Абысь $\{m a\}$, nопь (f.9r) & Abys $\{$ Tatar $\}$, priest \\
\hline 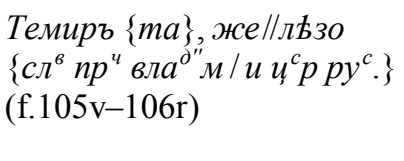 & $\begin{array}{l}\text { Temir }\{\text { Tatar }\} \text {, iron }\{\text { The } \\
\text { tale about the immaculate } \\
\text { Theotokos of Vladimir, } \\
\text { Russian kingdom }\end{array}$ \\
\hline
\end{tabular}




\begin{tabular}{|c|c|c|}
\hline $\begin{array}{l}\text { Дербылиь }\{\text { пур }\}, \text { игумень } \\
(\mathrm{f} .97 \mathrm{v})\end{array}$ & Derbysh $\{$ Turkish $\}$, abbot & cf. derviş \\
\hline 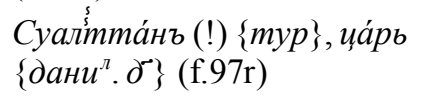 & $\begin{array}{l}\text { Sualtan }\{\text { Turkish }\}, \text { tsar } \\
\{\text { Daniel } 4\}\end{array}$ & cf. sultan \\
\hline $\begin{array}{l}\text { Сеитыл }\{\text { тур }\}, \text { вл кы сїирьчь } \\
\text { жблада/тели земли (f.97v) }\end{array}$ & $\begin{array}{l}\text { Seity }\{\text { Turkish }\}, \text { lords, } \\
\text { that is land possessors }\end{array}$ & cf. seyyid \\
\hline
\end{tabular}

Some entries explain words from Church Slavonic or Old Russian language which departed from the Russian lexical system:

\begin{tabular}{|c|c|}
\hline Вертогра $^{\partial}$, wəopo $^{\partial}$ (f.28r) & Vertograd, garden \\
\hline $\begin{array}{l}\text { Древле }\{c л\}, \text { прежде / йли в пре }{ }^{\partial} \text { нала } \\
\text { времена }\left\{\kappa \partial e^{6} p .(!) m \vec{\imath} .\right\} \text { (f.36v) }\end{array}$ & $\begin{array}{l}\text { Drevle }\{\text { Slavonic }\}, \text { earlier or in former } \\
\text { times }\{\text { Epistle to the Hebrews } 303\}\end{array}$ \\
\hline Степень, льстви/ича $\left\{\partial ъ a^{H} . \overrightarrow{M .}\right\}$ (f.100r) & Stepen', ladder $\{$ Acts 40$\}$ \\
\hline 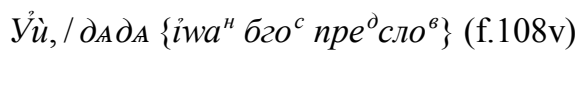 & $\begin{array}{l}\text { Ui, uncle }\{\text { The Preface of John the } \\
\text { Apostle\} }\end{array}$ \\
\hline УсерАзи, серги $\left\{\ddot{c} х о^{\partial}\right\}$ (f.109r) & Useryasi, ear-rings $\{$ Exodus $\}$ \\
\hline
\end{tabular}

The words marked as Czech are especially interesting. The same words in the Novgorod manuscript lexicon of 1596 (Russian National Library, Pogodin's collection, № 1642) and some other lexicons are marked as Polish. Most of them can be found in Belorussian and Ukrainian historical dictionaries and are considered to be Old Ruthenian words; some are Common Slavic. The source from which they came to the lexicon is unknown:

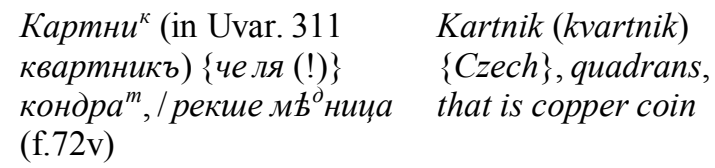

Креска $\{$ чес\}, че/pmà Kreska $\{$ Czech $\}$, stroke (f.72v)

Лакну $\{ч е\}$, взалка $/ с я$ (f.75r)
Laknul $\{$ Czech $\}$, got hungry

Nechekasha, did not take care or neglected

Pushcha $\{$ Czech $\}$, desert cf. Old Polish kwartnik' an old fractional gold coin used in Poland in the 14th and 15th cent.' (SP16 11: 607-608), Old Belorussian квартникъ 'an old fractional coin' (HSBM 15: 16) cf. Czech kreska, Old Belorussian креска 'line, mark' (HSBM 16: 116) cf. Old Czech taknąć (SP16 12: 450-451), Old Belorussian лакнути 'to be hungry' (HSBM 16: 281-282) cf. Polish czekać 'to wait', Czech čekat 'to wait' cf. Old Russian nyma 'desert place', Czech poušt ' desert place', Polish puszcza 'dense forest' 
Of course, many words have no language marks, although we can easily determine their origin. Moreover, not all language inscriptions are correct. Sometimes, the compilers overwrite not the language of word origin but the language from which the whole text in which the word occurred was translated into Russian. Or, it could be connected with the name of the book: Aфupa, a loanword from Greek $\dot{\alpha} \vartheta \dot{\eta} \rho \alpha$, has the mark ezu 'Egyptian', most likely because it was taken from the Egyptian Patericon (Historia Monachorum in Aegypto). The same language may have different marks: г (an abbreviation for гречески 'Greek') and ели (i.e. еллински 'Hellenic') for Greek, ри (i.e. римски 'Roman') and ла (i.e. латински 'Latin') for Latin, and so on. As the compiler writes in the Preface, "ï a ${ }^{3}$ ть рьчи, táкож в писа́нїи /

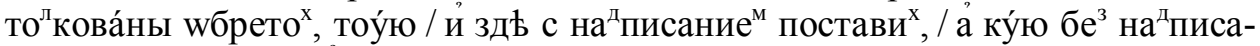

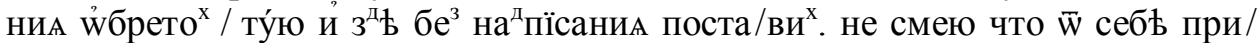
ложити" (f.5v) - "And I, those words, the same way as I had found in the manuscript, so here with inscriptions gave, and which one without inscription, so here without inscription gave. I durst not anything from myself add". Nevertheless, this testifies to the compiler's interest and attempt to determine word origin using all available means.

In the margins, compilers usually wrote the literary sources from which the words came into the lexicons (if they knew them). These are the Gospels of Matthew, Mark, Luke, and John with pericope numbers, Acts of the Apostles, Epistles, and the Book of Revelations. Then, in almost all the protocanonical books of the Old Testament, one can find in the margins of the lexicon: Genesis, Exodus, the Books of Samuel, Kings, and Chronicles, Joshua, Ezra, Nehemiah, Esther, Job, Psalms, Ecclesiastes, Isaiah, Lamentations, Ezekiel, Daniel; and deuterocanonical books as well: Judith, Wisdom of Solomon, Wisdom of Joshua ben Sira, and the Books of the Maccabees.

In addition to these, there are the marks to the works of the Holy Fathers: The Ladder of Divine Ascent of John Climacus, Homilies of Gregory of Nazianzus, works of Dionysius the Areopagite, Saint John of Damascus, Ephrem the Syrian, Dorotheus of Gaza, Maximus the Greek. Sometimes, the compiler mentioned only the names of compilations, not the particular text, for example, the compilations Chep' Zlataya (Golden Chain) or Zlatostruy.

Biographies of the Orthodox saints form a considerable part of the literary sources. The compiler used more than 20 hagiographical texts which were very popular in that period. Among the saints whose biographies we can find in the margins are famous theologians and writers (John of Damascus, John Chrysostom, John Climacus, Epiphanius of Salamis, Arsenius the Great, Theodore the Studite), hermits and ascetics (Anthony the Great, Mary of Egypt, Athanasius the Athonite, Onuphrius of Egypt, Sabbas the Sanctified, Sava of Serbia, Simeon the Holy Fool, John the Merciful, Saint Menas - the Martyr and Wonder-worker, one of the bestknown Egyptian saints), and martyrs (Saint George, Demetrius of Thessaloniki). Then, the compiler used the Patericon - a collection of stories about saints, martyrs, and hierarchs, and tales about them, and Synaxarion - collections of stories about feasts and the lives of saints arranged according to the twelve months of the year. 
Biographies of the saints were the favourite genre. Oleg Tvorogov wrote that "the value of the translated hagiography in Old Russian literature is exclusively great: biographies of the saints, along with sacred Scripture and homiletics, created the medieval Christians' ideology, and biographies of the saints were the basic source of information about the history of the world and the history of the church, along with chronicles" (Tvorogov 2008: 3).

Historical and geographical books were much rarer in those times, and only a few of them are mentioned in the lexicon: the Christian Topography by Cosmas Indicopleustes, Explanatory Palaea, Chronicle (Greek and Roman kingdoms), and Alexandria.

The main subject groups are determined by the literary sources: a lot of words related to Christian lifestyle and Jewish geographical names connected with the lives of Jesus Christ and the Apostles came from the Gospels as well as theological books:

Комкание $\{2\}$, прича/стие, е́же $e^{c}$ ть приатие бжї/ $u^{x}$ таинь $\left\{\text { ерре } e^{\mu} n \partial\right\}^{2}$ (f.58r)

Капернаумь $\{$ ев $\}$, домъ утьие/ниА $\left\{e v^{2} . l w^{H} .3\right\}$ (f.63r)

Пасха, преведение, / или свобода \{гри ${ }^{2}$ бго $\left.{ }^{c} \cdot \vec{a}\right\}(\mathrm{f} .86 \mathrm{v})^{3}$

Псевдопроөити/ся, люепророкъ $\left\{\right.$ маз̆ $\left.u^{M} 2 p e^{\kappa} . \overrightarrow{\theta_{3}}\right\}$ (f.90v)

Скрижали, двъ доще $е$ ки / истесаны ис камени самөи/ра, на ни же написа бгъ .i. за/поведеи ӥильлтяяно ${ }^{M}(!)\left\{\right.$ евре . $^{\mu}$ $m \overrightarrow{\kappa a}\}$ (f.96v)

Херуви $^{M}$, многъ разу ${ }^{M}, /$ и прем ${ }^{\partial}$ рость $\left\{\right.$ деwни ${ }^{c}$ ape $\left.^{n}.\right\}(\mathrm{f} .112 \mathrm{r})$
Komkanie $\{$ Greek\}, communion, that is taking God's sacraments \{Ephrem the Syrian, 84 (actually 85)\}

Kapernaum $\{$ Jewish\}, a house of comfort \{Gospel of John 7\}

Paskha, transferring or freedom \{Gregory of Nazianzus 1\}

Psevdoprofitisya, a false prophet \{Maximus the Greek 9, 7 (actually 7)\}

Skrizhaly, two tablets hewing out from the sapphire stone on which God wrote ten commandments to the Israelites $\{$ Epistle to the Hebrews 321 (actually 320)\}

Kheruvim, good sense and wisdom \{Dionysius the Areopagite\}

Historical books of the Bible, chronicles, and geographical books brought names of different places, descriptions of real and mythological peoples, animals, and plants. The Epiphanius of Salamis's story On the Twelve Gems (About Ephod), which was included in Palea, describes various gems and their magic qualities:

Адамать (in Uvar. 311 адаманть) $\{2\}$, камень зело че/стен $\{$ о еөуде $\}$ (f.12r)
Adamant $\{$ Greek $\}$, a very precious jewel $\{$ About ephod $\}$

\footnotetext{
${ }^{2}$ See Ephrem the Syrian's Homily 85 : http://old.stsl.ru/manuscripts/medium.php?col=1\&manuscript $=007$ \&page $=146$.

${ }^{3}$ See Gregory of Nazianzus's first homily about Easter: http://old.stsl.ru/manuscripts/medium. php?col=1\&manuscript=136\&pagefile=136-0009.
} 
Даөни/A, гра ар ираклА, а’ инде пите/тсл даөния по еллински дре́/вцее блгоуханно

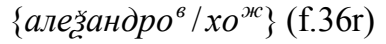

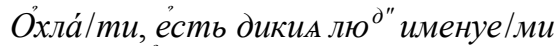

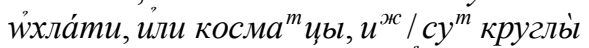
косма́ты черны̀ $\dot{w} /$ бличе иммще лво́во \{алез̆ $a^{\mu}$ дрїя.\} (f.84v)

Ӧненус (in Uvar. 311 огенусъ), / пи́ше ${ }^{m}$, láко е́сть во индиски й страна $^{x}$ древо, наричемо '́́ сне/нусь (in Uvar. 311 огенусъ), $u^{ж}$ во жони не гори ${ }^{m}, u$ ни же не

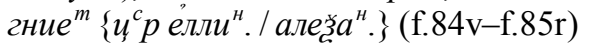

Тигръ, / звърь лют , и паки тигръ е $e^{c}$ ре/ка. б. часть реки $u^{3}$ ше иил $u^{3}$ pa/A; сиА проходи ${ }^{m}$ землю асирї/искую, а’ инде nuше $^{m}$, пигрь, / вътрь острь $\left\{u^{c} p\right.$ гре $e^{u} /$ $\left.\sigma b l^{m} . \overrightarrow{2}\right\}(\mathrm{f} .105 \mathrm{v})$
Daphnia, town Irakleia, in other places Daphnia is meant in Greek a fragrant tree $\{$ Alexander's travelling

Okhlaty, people named okhlaty or kosmattsy, which are round, black, shaggy and lionlike $\{$ Alexandria $\}$

Ogenus, it is written to be a tree named ogenus in the Indian land, which can not be berried \{Greek kingdom, Alexandria\}

The names of representatives of the church hierarchy, civil and military authorities, and some proper names of famous people (tsars, poets, philosophers, and so on) also came from historical books.

Димостенъ еллинскии өило/соөъ бъ

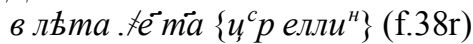

Куви/куларие $\left\{p^{\prime \prime}\right\}$, постелничеи

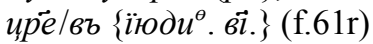

Протосигкел , / болии" келеиникь патриарше/скои, $u^{ж}$ мелоे честенъ $\left\{u^{c} p\right.$ греч $\}(\mathrm{f} .87 \mathrm{v})$

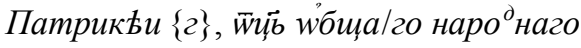
промышления $\left\{u^{c} p\right.$ гре $e^{u}$ (f.87v)

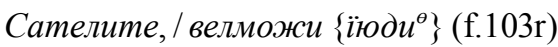

Dimosten, there was a Greek Philosopher in year 5301 (207 B.C.) \{Greek kingdom\}

Kuvicularie $\{$ Roman $\}$, the gentelman of the king's badchamber \{Judith 12\}

Protosigkel, the main patriarch cellattendant $\{$ Greek kingdom\}

Patrikie, the father of the common folk care \{reek kingdom $\}$

Satelite, noble people $\{$ Judith $\}$

In addition to these sources, there are some others which are not mentioned in the lexicons but we can distinguish them. These are glossaries which had been compiled before. One of them is "The interpretation of obscure words" explaining incomprehensible words from an archaic translation of John Climacus's The Ladder of Divine Ascent (further detailed in KovTun 1963: 216-268, TRIFUNOVICH 1982). "The interpretation" is just a list of Serbian words which would be unknown to a Russian reader (one of the first translations of The Ladder was made in Serbia and then came to Russia). In the lexicon, all the entries are ordered alphabetically. 
Some entries (such as Smilax, for example) came from theological comments to The Ladder which exist in some manuscripts:

Гадани/е, сокровень глаго (f.33r)

Ръснотивие, йсти/нство (f.92v)

Сво/иство, ёже ими ${ }^{m}$ что осо ${ }^{\sigma}$ но (f.102r)

Тризна, подвигъ \{льст. б.\} (f.106v)

Уӟро́къ, вина̀ (f.108v)

Смилаз̆ъ $\{2\}$, трава, иже по/добна

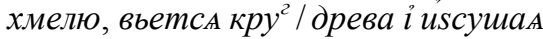
его кръпо/стию своею $(\mathrm{f} .99 \mathrm{v})$
Gadanie, secret word

Resnotivie, truth

Svoistvo, what is one has particularly

Trizna, deed $\{$ Ladder, Step 4$\}$

Uzrok, blame

Smilax $\{$ Greek\}, the grass which is like hop creeps around a tree withering it by its strength

The other lexicographical source is the Explanations for proper names alphabetically by Maximus the Greek (further detailed in KovTuN 1975: 116-205). After the Christianization of Russia, newborn babies were given the names of saints, most of which had a Greek origin. The meaning of these names was unclear. Maximus the Greek translated Greek and some Latin names into Russian, and a large number of the names translated in his dictionary have been used in the lexicon. They formed the last part of each letter division, called "Human Names":

\begin{tabular}{|c|c|}
\hline Анастасїи, воскр ${ }^{c}$ ние (f.23r) & Anastasiy, resurrection \\
\hline Варнава, / снъ утьшениА (f.30v) & Varnava, the son of comfort \\
\hline Калистра ${ }^{m}\{2\}, /$ добрыли во́инъ (f.70v) & Kalistrat $\{$ Greek $\}$, good warrior \\
\hline Ма/карие $\{2\}$, бльсенныи (f.79r) & Makarie, blessed \\
\hline ПелагиА, пучина (f.91r) & Pelagia, the deep \\
\hline
\end{tabular}

Apart from the above-mentioned ones, there are a lot of entries in which it is difficult to classify and determine what sources they were taken from. Most of these words are of Greek origin and we can only suppose that their source was something like a Greek-Russian dictionary. The others are lexical variants which were usually written in the margins as a result of the editor's correction of texts.

Here, we have investigated only two lexicons of the first type but they have an extremely important place in Russian lexicography because other lexicons of the first and other types were compiled on their basis. For example, Nil Kurlyatev made a new edition by reducing some large entries of the O.XVI.1 and adding new ones, and the new edition of the basic lexicon appeared. Gradually, new entries enlarged the volume more and more but all the lexicographical principles (e.g. the structure of entries, the alphabetical organisation, or the types of references) were kept almost unchanged. Only in 1596, in Novgorod the Great, a new type of lexicon was created: the compiler organized the entries not only according to the first letter but also taking into consideration the next vowel letter. Moreover, he used 
some rules organizing the entries within every letter subdivision. Nevertheless, even there, most features of the first lexicons were preserved, which confirms their key role in the development of Russian lexicography.

\section{References}

HSBM = Гістарычны слоўнік беларускай мовы. Т. 1-21. Мінск: «Навука і тэхніка», 1982-2002.

Kovtun 1963 = Ковтун Л. С. Русская лексикография эпохи средневековья. Москва: «Издательство АН СССР», 1963.

Kovtun 1975 = Ковтун Л. С. Лексикография в Московской Руси XVI- начала XVII 8. Ленинград: «Наука», 1975.

Kovtun $1989=$ Ковтун Л. С. Азбуковники XVI-XVII вв. (старшая разновидность). Ленинград: «Наука», 1989.

SP16 = Stownik polszczyzny XVI wieku. T. 1-34. Wrocław: Wydavnictwo Polskiej Akademii Nauk, 1966-2010.

TRIFUNOVICH 1982 = Трифуновић Ђ. Речник уз српске преписе Лествице: прилог познавању српске средњовековне лексикофрафије. Јужнословенски филолог 38 (1982): $81-82$.

TVorogov 2008 = Творогов О. В. Переводные жития в русской книжности XI-XV вв. Каталог. Москва-Санкт-Петербург: «Альянс-Архео», 2008. 